\title{
PENERAPAN METODE PENGINDERAAN JAUH DAN SISTEM INFORMASI GEOGRAFIS UNTUK ANALISA PERUBAHAN PENGGUNAAN LAHAN (Studi Kasus: Kawasan Danau Maninjau)
}

\author{
Afrital Rezki \\ Program Studi Pendidikan Geografi, STKIP PGRI Sumatera Barat \\ Email: afrital.rezki@gmail.com
}

\begin{abstract}
Studies of changes in land use is very important, because changes in land use have an impact on the physical and social environment. The purpose of this study was to determine the use and change of spatial land in the area of Lake Maninjau by using satellite images and research in the field. The method used is the method of remote sensing image interpretation, survey method and descriptive analysis based spatial. Land use has changed between 1989 and 2014. The use of the forest land is the largest change is an area of 1989 ha 32.350.59, 27.580.50 20.175.93 ha ha in 2002 and 2014. The pattern of land use changes spatially in Region Maninjau follow the main activity of most of the population in agriculture. Most forest land is converted. Forest land converted to mixed farms are the most extensive in Nagari Tanjung Sani on the west side of the lake Maninjau (30 $565 \mathrm{ha}$ ) and in Nagari Sungai Batang in the east of the lake Maninjau (31 831 ha).
\end{abstract}

Keywords: changes in land use, satellite images, field checks, the Lake Maninjau

\begin{abstract}
Abstrak
Penelitian tentang perubahan penggunaan lahan sangat penting dilakukan, karena perubahan penggunaan lahan memiliki dampak terhadap lingkungan fisik dan sosial. Tujuan dari penelitian ini adalah untuk mengetahui penggunaan dan perubahan lahan secara spasial di Kawasan Danau Maninjau dengan menggunakan citra satelit dan penelitian di lapangan. Metode penelitian yang digunakan adalah metode interpretasi citra penginderaan jauh, metode survey, dan analisis deskriptif berbasis keruangan. Penggunaan lahan telah mengalami perubahan antara tahun 1989 dan 2014. Penggunaan lahan hutan merupakan yang terluas mengalami perubahan yaitu seluas 32.350 .59 ha tahun 1989, 27.580.50 ha tahun 2002 dan 20.175.93 ha tahun 2014. Pola perubahan penggunaan tanah secara spasial di Kawasan Danau Maninjau mengikuti kegiatan utama sebagian besar penduduk di bidang pertanian. Lahan hutan paling banyak diubah. Lahan hutan yang diubah menjadi kebun campuran paling luas terdapat di Nagari Tanjung Sani di sebelah barat danau Maninjau (30.565 ha) dan di Nagari Sungai Batang di sebelah timur danau Maninjau (31.831 ha).

Kata Kunci: perubahan penggunaan lahan, citra satelit, cek lapangan, Kawasan Danau Maninjau
\end{abstract}




\section{PENDAHULUAN}

Perkembangan penggunaan tanah bergerak horisontal secara spasial ke arah wilayah-wilayah yang mudah diusahakan. Penggunaan tanah juga bergerak secara vertikal dalam rangka menaikkan mutunya (Kartono et al, 1989). Yang menjadi pemicunya adalah pertambahan penduduk yang meningkatkan kebutuhan akan tanah dalam rangka menaikkan pendapatan untuk pemenuhan kebutuhan dan menaikkan taraf hidupnya.

Kehidupan masyarakat di sekitar Kawasan Danau Maninjau didominasi oleh masyarakat yang menyandarkan hidupnya berbasis agraria. Perkembangan penggunaan tanah secara spasial di Kawasan Danau Maninjau dibatasi oleh faktor fisik yang didominasi oleh kemiringan lereng curam. Pertumbuhan pemukiman di sekitar danau mengakibatkan pemanfaatan ruang menjadi tumpang tindih.

Perkembangan penggunaan tanah tersebut telah menimbulkan trade off dimana naiknya pendapatan masyarakat diikuti oleh penurunan kualitas lingkungan dan sebaliknya. Fenomena yang terjadi di Kawasan Danau Maninjau merupakan fenomena yang kompleks yang menyinggung tiga komponen pengelolaan lingkungan hidup berkelanjutan yaitu sosial, ekonomi dan lingkungan

Dari fakta yang terdapat di Kawasan Danau Maninjau dapat di kemukakan bahwa Kawasan Danau Maninjau merupakan tempat yang bersejarah dan disertai dengan keindahan alam, Danau Maninjau juga merupakan sumber penghidupan bagi masyarakat setempat, tetapi perubahan penggunaan tanah yang terjadi hari ini mengancam keberlanjutan kawasan danau, baik dari segi ekonomi maupun ekosistem danau itu sendiri. Berdasarkan latar belakang diatas, maka dirumuskan masalah penelitian sebagai berikut: bagaimanakah penggunaan tanah secara spasial di Kawasan 
Danau Maninjau, dan bagaimanakah pola perubahan penggunaan tanah secara spasial di Kawasan Danau Maninjau.

\section{METODE PENELITIAN}

Penelitian ini menggunakan metode interpretasi citra penginderaan jauh, GIS, metode survey, dan analisis deskriptif berbasis keruangan. Interpretasi citra penginderaan jauh dilakukan untuk mengetahui informasi jenis penggunaan lahan aktual dan tahun-tahun terdahulu berdasarkan nilai digital yang terekam pada data penginderaan jauh. Metode survey lapangan dilakukan untuk mengetahui hasil interpretasi yang meliputi jenis penggunaan lahan, identifikasi kondisi hidrologi, morfologi berupa lereng dan kondisi lingkungan. Lokasi penelitian dilakukan di Kawasan Danau Maninjau Kecamatan Tanjung Raya Kabupaten Agam Provinsi Sumatera Barat. Waktu pelaksanaan penelitian secara keseluruhan dilaksanakan selama 3 bulan yaitu sejak September sampai November 2014.

Bahan-bahan yang digunakan dalam penelitian ini adalah Citra satelit Landsat akuisisi tahun 1989, 2002 dan 2014 yang diperoleh dari USGS untuk memperoleh informasi perubahan penggunaan lahan, peta topografi digital daerah Maninjau, data ketinggian yang diperoleh dari pengolahan digital elevation model (DEM), data curah hujan tahunan yang diperoleh dari BMKG, data tutupan vegetasi yang diperoleh dari pengolahan citra satelit, data penggunaan lahan dan data batas Daerah Aliran Sungai yang diperoleh dari analisis DEM dan peta topografi.

Alat-alat yang digunakan dalam penelitian ini adalah: Global positioning system (GPS) Garmin, abney level, Alat tulis, kuisioner dan kamera untuk dokumentasi lapangan, perangkat komputer beserta perangkat lunak yang digunakan untuk pengolahan hingga analisis data. Jenis data dalam penelitian ini terdiri atas data primer dan data sekunder. Data primer merupakan data yang diperoleh melalui survey dan pengukuran langsung di lapangan. 
Sedangkan data sekunder terdiri dari data-data hasil observasi pada instansi terkait.

Setelah data diperoleh dilakukan analisis terhadap data melalui 3 jalur kegiatan secara bersamaan, yakni reduksi data, penyajian data, dan penarikan kesimpulan (Miles \& Huberman, 1992:16). Informasi penggunaan lahan diperlukan untuk memperoleh informasi dan proses klasifikasi perkembangan struktur dan pola penggunaan lahan di daerah penelitian. Dalam proses klasifikasi dilakukan gabungan antara klasifikasi supervised dan unsupervised. Klasifikasi supervised dilakukan setelah proses segmentasi yang tergolong metode unsupervised, segmentasi merupakan proses pembagian region berdasarkan algoritma pixel based yang kemudian dilanjutkan dengan pemberian sampel berdasarkan obyek dan hasil survey sehingga segmentasi dapat dijadikan sebagai batas klasifikasi. Proses ini menggunakan trainning sample yang menggunakan pendekatan pola, rona, warna, dan asosiasi dengan metode nearest neighbor dan dibantu dengan manual editing.

\section{Alur kerja penelitian dan Proses Penelitian}

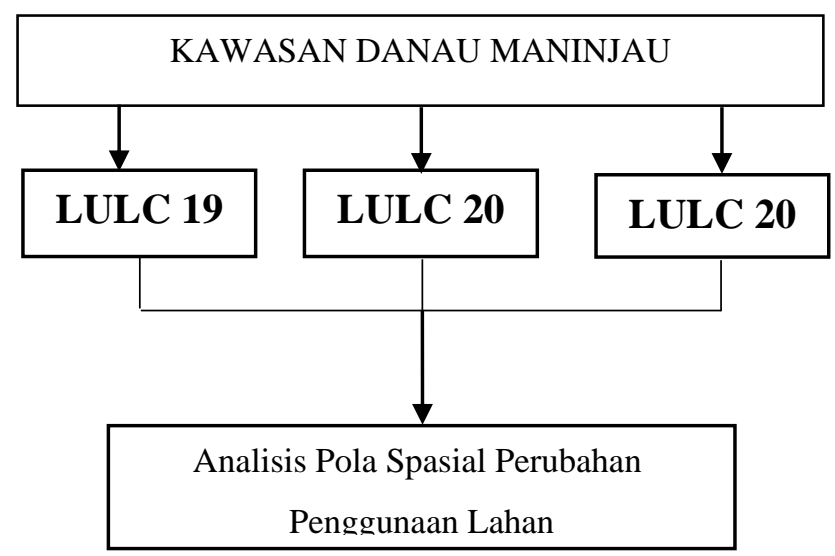

Pola Spasial Perubahan Penggunaan Lahan 
Pola spasial perubahan penggunaan lahan diperoleh dengan membandingkan pola spasial yang terjadi pada tahun aktual dengan tahun pengamatan sebelumnya. Dari hasil analisis tersebut akan didapat luasan, arah dan kecenderungan perkembangan dan perubahan dari setiap jenis penggunaan lahan dalam kurun waktu dua titik pengamatan tersebut.

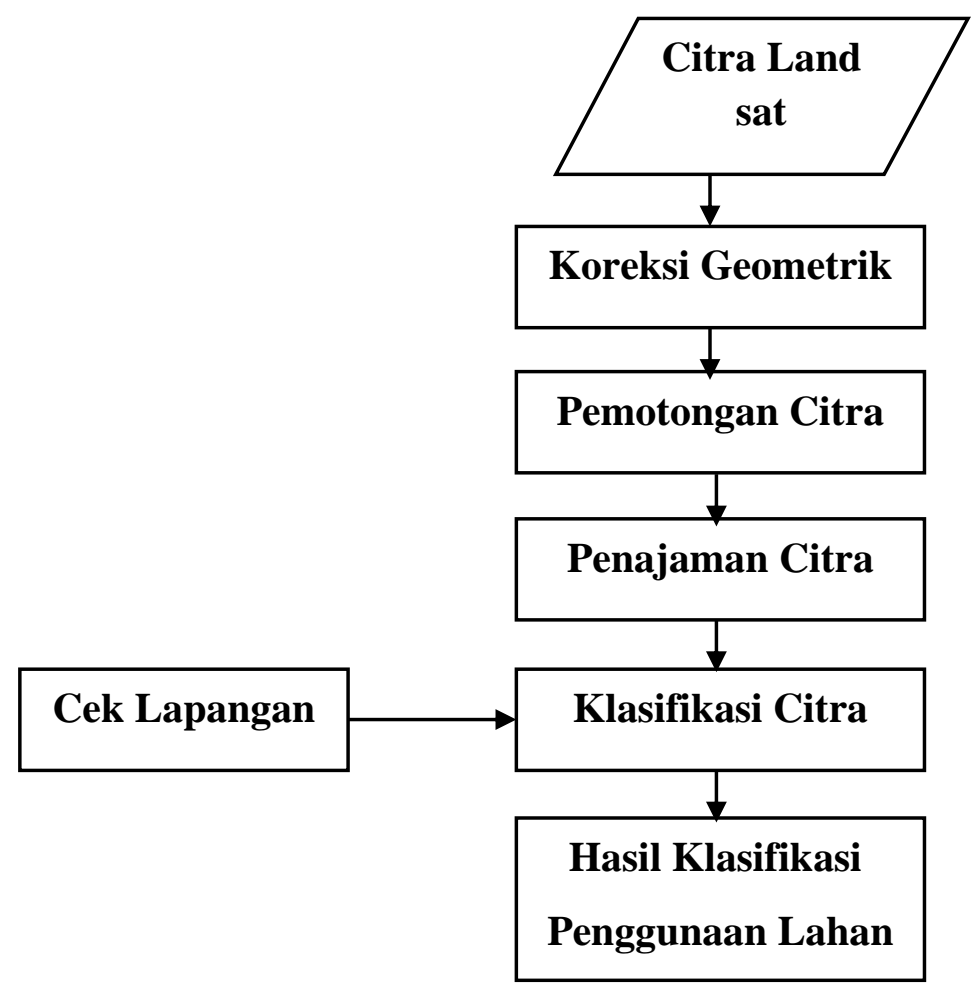

Proses Interpretasi Citra Landsat Untuk Memperoleh Penggunaan Lahan

Cek-lapangan juga diperlukan sebagai sebagai salah cara untuk membantu meningkatkan akurasi dalam proses klasifikasi. Dalam penelitian ini juga dilakukan beberapa koreksi seperti geometrik untuk meningkatkan keakuratan posisi kordinat dan penajaman citra untuk meningkatkan kualitas visual data citra. 


\section{PEMBAHASAN}

Hasil Penelitian

Penggunaan lahan merupakan wujud dari kegiatan manusia dalam memperlakukan sebidang tanah. Perlakuan terhadap tanah tersebut memiliki dasar yang berbeda-beda tergantung pada kebutuhan masyarakat.

Tabel 1. Luas Penggunaan Lahan di Kawasan Danau Maninjau tahun 1989, 2002, dan 2014

\begin{tabular}{|l|c|c|c|c|c|r|}
\hline \multicolumn{1}{|c|}{$\begin{array}{c}\text { Kelas } \\
\text { Penggunaan }\end{array}$} & $\begin{array}{c}1989 \\
\mathrm{Ha}\end{array}$ & $\%$ & $\begin{array}{c}2002 \\
\mathrm{Ha}\end{array}$ & $\%$ & $\begin{array}{c}2014 \\
\mathrm{Ha}\end{array}$ & $\%$ \\
\hline Badan air & $9,738.99$ & 12.71 & $9,738.99$ & 12.71 & $9,738.99$ & $\begin{array}{r}12.7 \\
1\end{array}$ \\
\hline Hutan & $32,350.59$ & 42.22 & $27,580.50$ & 35.99 & $20,175.93$ & $\begin{array}{r}26.3 \\
3\end{array}$ \\
\hline $\begin{array}{l}\text { Kebun } \\
\text { campuran }\end{array}$ & $16,107.57$ & 21.02 & $18,841.32$ & 24.59 & $24,018.48$ & $\begin{array}{r}31.3 \\
4\end{array}$ \\
\hline Ladang & $7,586.37$ & 9.90 & $9,772.92$ & 12.75 & $11,454.75$ & $\begin{array}{r}14.9 \\
5\end{array}$ \\
\hline Sawah & $2,767.41$ & 3.61 & $2,735.55$ & 3.57 & $2,685.15$ & 3.50 \\
\hline $\begin{array}{l}\text { Semak } \\
\text { belukar }\end{array}$ & $7,547.31$ & 9.85 & $7,253.01$ & 9.47 & $7,406.73$ & 9.67 \\
\hline $\begin{array}{l}\text { Lahan } \\
\text { terbuka }\end{array}$ & 104.49 & 0.14 & 7.92 & 0.01 & 29.70 & 0.04 \\
\hline Terbangun & 425.43 & 0.56 & 697.95 & 0.91 & $1,118.43$ & 1.46 \\
\hline \multicolumn{1}{|c|}{ Total } & $76,628.16$ & $\begin{array}{c}100.0 \\
0\end{array}$ & $76,628.16$ & $\begin{array}{r}100.0 \\
0\end{array}$ & $76,628.16$ & $\begin{array}{c}100 . \\
00\end{array}$ \\
\hline
\end{tabular}

Sumber : Data Hasil Olahan Interpretasi citra Landsat tahun 1989, 2002 dan 2014

Tahun 1989, terlihat hutan masih mendominasi penggunaan lahan di Kawasan Danau Maninjau seluas 32,350.59 ha. Tahun 2002 terjadi perubahan yang mencolok pada penggunaan lahan hutan yaitu tersisa 27,580.50 ha. Sedangkan penggunaan lahan hutan pada tahun 2014 berkurang menjadi 20,175.93 ha saja. 


\section{Perubahan Penggunaan Lahan dari Tahun 1989 ke Tahun 2014}

Berdasarkan perhitungan yang dilakukan dan analisis terhadap setiap perubahan penggunaan lahan dari tahun 1989 sampai pada tahun 2014 dapat dilihat arah perubahannya. Perubahan penggunaan lahan hutan dari tahun 1989 ke tahun 2002 terlihat kearah kebun campuran seluas 3.687,48 ha. Perubahan penggunaan lahan hutan kearah penggunaan lahan ladang seluas 203.94 ha. Perubahan penggunaan lahan hutan kearah penggunaan lahan semak belukar seluas 868.86 ha. Perubahan penggunaan lahan hutan kearah penggunaan lahan terbuka menjadi $0.36 \mathrm{ha}$, dan perubahan penggunaan lahan hutan kearah penggunaan lahan terbangun menjadi 9.45 ha.

Perubahan Penggunaan Lahan dari Tahun 2002 ke Tahun 2014

Dari tahun 2002 sampai tahun 2014 perubahan penggunan lahan hutan menjadi penggunaan lahan kebun campuran seluas 6.262 .65 ha, perubahan penggunaan lahan hutan menjadi penggunaan lahan ladang seluas $1,118.70$ ha. Sedangkan perubahan penggunaan lahan hutan menjadi penggunaan lahan semak belukar adalah seluas 9.09 ha, perubahan penggunaan lahan hutan menjadi penggunaan lahan terbuka seluas 0.90 ha, dan perubahan penggunaan lahan hutan menjadi penggunaan lahan terbangun seluas 13.23 ha. Dari total luas hutan yang berubah dari tahun 2002 ke 2014 yang paling besar adalah perubahan ke arah penggunaan lahan kebun campuran.

Penggunaan lahan semak belukar antara tahun 2002 sampai tahun 2014 menjadi penggunaan lahan ladang seluas 389,34 ha, sedangkan perubahan Penggunaan lahan semak belukar menjadi lahan terbuka seluas 1,17 ha, dan perubahan penggunaan lahan semak belukar menjadi penggunaan lahan terbangun adalah seluas 101,70 ha. Dari angka perubahan tersebut terlihat bahwa tinggkat perubahan yang paling besar dari penggunaan lahan semak belukar dari tahun 2002 sampai tahun 2014 adalah terhadap penggunaan lahan terbangun. Untuk penggunaan lahan terbuka dari tahun 2002 sampai 
tahun 2014 tidak mengalami perubahan sedikitpun. Sama halnya dengan penggunaan lahan terbangun juga tidak mengalami perubahan terhadap penggunaan lahan lainnya. Seperti yang ditunjukkan dalam (Tabel 5.1.3 dan tabel 5.1.4).

Tabel 1. Perubahan Luas Penggunaan Lahan di Kawasan Danau Maninjau tahun 1989 ke 2002

\begin{tabular}{|c|c|c|c|c|c|c|c|c|c|c|}
\hline \multirow{2}{*}{\multicolumn{2}{|c|}{$\begin{array}{c}\text { Perubahan } \\
\text { 1989-2002 } \\
\text { (ha) }\end{array}$}} & \multicolumn{8}{|c|}{ Luas Tahun 2002 (ha) } & \multirow{3}{*}{$\begin{array}{c}\begin{array}{c}\text { Jumlah } \\
\text { Tahun } \\
1989\end{array} \\
9,738.99\end{array}$} \\
\hline & & \multirow{2}{*}{$\begin{array}{r}\text { Badan air } \\
9,738.99\end{array}$} & \multirow{2}{*}{$\begin{array}{l}\text { Hut } \\
\text { an }\end{array}$} & \multirow{2}{*}{$\begin{array}{c}\text { Kebun } \\
\text { Campur } \\
\text { an }\end{array}$} & \multirow{2}{*}{$\begin{array}{l}\text { Lad } \\
\text { ang }\end{array}$} & \multirow{2}{*}{$\begin{array}{c}\text { Saw } \\
\text { ah }\end{array}$} & \multirow{2}{*}{$\begin{array}{c}\text { Semak } \\
\text { Belukar }\end{array}$} & \multirow{2}{*}{$\begin{array}{l}\text { Tanah } \\
\text { terbuka }\end{array}$} & \multirow{2}{*}{$\begin{array}{l}\text { Wilayah } \\
\text { Terbangun }\end{array}$} & \\
\hline \multirow{8}{*}{ 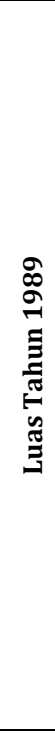 } & $\begin{array}{l}\text { Badan } \\
\text { air }\end{array}$ & & & & & & & & & \\
\hline & Hutan & & $\begin{array}{r}27,5 \\
80.5 \\
0\end{array}$ & $3,687.48$ & $\begin{array}{r}203 . \\
94\end{array}$ & & 868.86 & 0.36 & 9.45 & $\begin{array}{r}32,350.5 \\
9\end{array}$ \\
\hline & $\begin{array}{l}\text { Kebun } \\
\text { camp } \\
\text { uran }\end{array}$ & & & $\begin{array}{r}14,606 . \\
46 \\
\end{array}$ & $\begin{array}{l}1,48 \\
0.86 \\
\end{array}$ & & & & 20.25 & $\begin{array}{r}16,107.5 \\
7 \\
\end{array}$ \\
\hline & $\begin{array}{l}\text { Ladan } \\
\text { g }\end{array}$ & & & & $\begin{array}{l}7,40 \\
1.69 \\
\end{array}$ & & & & 184.68 & $7,586.37$ \\
\hline & Sawah & & & & & $\begin{array}{l}2,73 \\
5.55 \\
\end{array}$ & 2.88 & & 28.98 & $2,767.41$ \\
\hline & $\begin{array}{l}\text { Semak } \\
\text { beluk } \\
\text { ar }\end{array}$ & & & 519.39 & $\begin{array}{r}654 . \\
75 \\
\end{array}$ & & $6,348.60$ & & 24.57 & $7,547.31$ \\
\hline & $\begin{array}{l}\text { Lahan } \\
\text { Terbu } \\
\text { ka } \\
\end{array}$ & & & 27.99 & $\begin{array}{r}31.6 \\
8 \\
\end{array}$ & & 32.67 & 7.56 & 4.59 & 104.49 \\
\hline & $\begin{array}{l}\text { Wilay } \\
\text { ah } \\
\text { Terba } \\
\text { ngun } \\
\end{array}$ & & & & & & & & 425.43 & 425.43 \\
\hline \multicolumn{2}{|c|}{$\begin{array}{c}\text { Jumlah } \\
\text { Tahun } 2002\end{array}$} & $9,738.99$ & $\begin{array}{r}27,5 \\
80.5 \\
0 \\
\end{array}$ & $\begin{array}{r}18,841.3 \\
2 \\
\end{array}$ & $\begin{array}{l}9,77 \\
2.92\end{array}$ & $\begin{array}{l}2,73 \\
5.55\end{array}$ & $7,253.01$ & 7.92 & 697.95 & $\begin{array}{r}76,628 . \\
16 \\
\end{array}$ \\
\hline
\end{tabular}

Tabel 2. Perubahan Luas Penggunaan Lahan di Kawasan Danau Maninjau tahun 2002 ke 2014

\begin{tabular}{|c|c|c|c|c|c|c|c|c|c|}
\hline \multirow[b]{2}{*}{$\begin{array}{l}\text { Perubahan } \\
2002-2014\end{array}$} & \multicolumn{8}{|c|}{ Luas Tahun 2014} & \multirow[b]{2}{*}{$\begin{array}{c}\text { Jumlah } \\
\text { Tahun } 2002\end{array}$} \\
\hline & $\begin{array}{c}\text { Ba } \\
\text { dan } \\
\text { air }\end{array}$ & Hutan & $\begin{array}{c}\text { Kebun } \\
\text { campu } \\
\text { ran }\end{array}$ & $\begin{array}{c}\text { Lada } \\
\text { ng }\end{array}$ & $\begin{array}{c}\text { Sawa } \\
\text { h }\end{array}$ & $\begin{array}{c}\text { Sem } \\
\text { ak } \\
\text { belu } \\
\text { kar }\end{array}$ & $\begin{array}{l}\text { Tanah } \\
\text { terbuka }\end{array}$ & $\begin{array}{c}\text { Wila } \\
\text { yah } \\
\text { Terb } \\
\text { angu } \\
\text { n } \\
\end{array}$ & \\
\hline
\end{tabular}




\begin{tabular}{|c|c|c|c|c|c|c|c|c|c|c|}
\hline \multirow{8}{*}{ 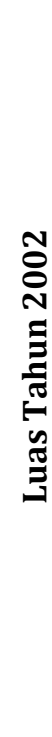 } & $\begin{array}{l}\text { Badan } \\
\text { air }\end{array}$ & $\begin{array}{r}9,7 \\
38 . \\
99\end{array}$ & & & & & & & & $9,738.99$ \\
\hline & Hutan & & $\begin{array}{r}20,175 \\
.93 \\
\end{array}$ & $\begin{array}{r}6,262 . \\
65 \\
\end{array}$ & $\begin{array}{r}1,118 \\
.70 \\
\end{array}$ & & 9.09 & 0.90 & 13.23 & $27,580.50$ \\
\hline & $\begin{array}{l}\text { Kebun } \\
\text { campura } \\
\text { n }\end{array}$ & & & $\begin{array}{r}17,755 \\
.83\end{array}$ & $\begin{array}{r}359.8 \\
2\end{array}$ & & $\begin{array}{r}636.8 \\
4\end{array}$ & 4.23 & 84.60 & $18,841.32$ \\
\hline & Ladang & & & & $\begin{array}{r}9586 . \\
89 \\
\end{array}$ & & & 15.48 & $\begin{array}{r}170.5 \\
5 \\
\end{array}$ & $9,772.92$ \\
\hline & Sawah & & & & & $\begin{array}{r}2,685 \\
.15 \\
\end{array}$ & & & 50.40 & $2,735.55$ \\
\hline & \begin{tabular}{|l|} 
Semak \\
belukar
\end{tabular} & & & & $\begin{array}{r}389.3 \\
4 \\
\end{array}$ & & $\begin{array}{r}6,760 \\
.80 \\
\end{array}$ & 1.17 & $\begin{array}{r}101.7 \\
0 \\
\end{array}$ & $7,253.01$ \\
\hline & \begin{tabular}{|l|} 
Lahan \\
terbuka
\end{tabular} & & & & & & & 7.92 & & 7.92 \\
\hline & $\begin{array}{l}\text { Terbang } \\
\text { un }\end{array}$ & & & & & & & & $\begin{array}{r}697.9 \\
5 \\
\end{array}$ & 697.95 \\
\hline & $\begin{array}{l}\text { lah Tahun } \\
2014\end{array}$ & $\begin{array}{r}9,7 \\
38 . \\
99 \\
\end{array}$ & $\begin{array}{r}20,175 \\
.93\end{array}$ & $\begin{array}{r}24,018 \\
.48\end{array}$ & $\begin{array}{r}11,45 \\
4.75\end{array}$ & $\begin{array}{r}2,685 \\
.15\end{array}$ & $\begin{array}{r}7,406 \\
.73\end{array}$ & 29.70 & $\begin{array}{r}1,118 \\
.43\end{array}$ & $76,628.16$ \\
\hline
\end{tabular}

\section{Nagari Paninjauan}

Tabel 4. Luas perubahan penggunaan lahan di Nagari Paninjauan dari tahun 2002 sampai tahun 2014

\begin{tabular}{|c|l|r|}
\hline No. & \multicolumn{1}{|c|}{$\begin{array}{c}\text { Kelas Perubahan Penggunaan Lahan } \\
\text { Nagari Paninjauan }\end{array}$} & $\begin{array}{r}\text { Luas } \\
\text { (Ha) }\end{array}$ \\
\hline 1 & Hutan menjadi Kebun campuran & 10.135 \\
\hline 2 & Hutan menjadi Ladang & 0.107 \\
\hline 3 & Kebun campuran menjadi Ladang & 0.092 \\
\hline 4 & Kebun campuran menjadi Semak belukar & 0.183 \\
\hline 5 & Kebun campuran menjadi Terbangun & 0.016 \\
\hline 6 & Ladang menjadi Terbangun & 0.099 \\
\hline 7 & Sawah menjadi Terbangun & 0.225 \\
\hline 8 & Semak belukar menjadi Ladang & 0.016 \\
\hline 9 & Semak belukar menjadi Terbangun & 0.093 \\
\hline & Total Perubahan & $\mathbf{1 0 . 9 6 6}$ \\
\hline
\end{tabular}

Sumber : Hasil olahan data Citra tahun 2002 dan 2014

Penggunaan lahan dari tahun 2002 ke tahun 2014 di Nagari Paninjauan mengalami perubahan dimana penggunaan lahan hutan menjadi 
penggunaan lahan kebun campuran seluas 10.135 ha, perubahan penggunaan lahan sawah menjadi penggunaan lahan terbangun seluas 0.225 ha. Sedangkan Kebun campuran menjadi semak belukar adalah seluas 0.183 ha, perubahan penggunaan lahan hutan menjadi penggunaan ladang seluas 0.107 ha, perubahan semak belukar menjadi terbangun adalah seluas 0.093 ha dan penggunaan lahan kebun campuran menjadi ladang seluas 0.092 ha. Dari total luas hutan yang berubah dari tahun 2002 ke 2014 yang paling besar adalah perubahan ke arah penggunaan lahan kebun campuran.

\section{Nagari Koto Kaciak}

Tabel 5. Luas perubahan penggunaan lahan di Nagari Koto Kaciak dari tahun 2002 sampai tahun 2014

\begin{tabular}{|c|l|r|}
\hline No. & \multicolumn{1}{|c|}{$\begin{array}{c}\text { Kelas Perubahan Penggunaan Lahan } \\
\text { Nagari Koto Kaciak }\end{array}$} & $\begin{array}{r}\text { Luas } \\
\text { (Ha) }\end{array}$ \\
\hline 1 & Hutan menjadi Kebun campuran & 24.568 \\
\hline 2 & Hutan menjadi Ladang & 1.244 \\
\hline 3 & Kebun campuran menjadi Ladang & 0.424 \\
\hline 4 & Kebun campuran menjadi Semak belukar & 0.373 \\
\hline 5 & Ladang menjadi Terbangun & 0.781 \\
\hline 6 & Sawah menjadi Terbangun & 0.332 \\
\hline 7 & Semak belukar menjadi Ladang & 0.581 \\
\hline 8 & Semak belukar menjadi Terbangun & 0.159 \\
\hline & Total Perubahan & $\mathbf{2 8 . 4 6 2}$ \\
\hline
\end{tabular}

Sumber : Hasil olahan data Citra tahun 2002 dan 2014

Penggunaan lahan dari tahun 2002 ke tahun 2014 di Nagari Koto kaciak mengalami perubahan dimana penggunaan lahan hutan menjadi penggunaan lahan kebun campuran seluas 24.568 ha, perubahan penggunaan lahan ladang menjadi penggunaan lahan terbangun seluas 0.781 ha. Sedangkan semak belukar menjadi ladang adalah seluas 0.581 ha, perubahan penggunaan lahan kebun campuran menjadi penggunaan ladang seluas 0.424 
ha, perubahankebun campuran menjadi semak belukar adalah seluas 0.373 ha dan penggunaan lahan sawah menjadi terbangun seluas 0.332 ha. Dari total luas hutan yang berubah dari tahun 2002 ke 2014 yang paling besar adalah perubahan ke arah penggunaan lahan kebun campuran.

\section{Nagari Koto Gadang}

\section{Tabel 3. Luas perubahan penggunaan lahan di Nagari Koto Gadang dari} tahun 2002 sampai tahun 2014

\begin{tabular}{|l|l|l|}
\hline No. & $\begin{array}{l}\text { Kelas Perubahan Penggunaan Lahan } \\
\text { Nagari Koto Gadang }\end{array}$ & $\begin{array}{l}\text { Luas } \\
(\mathbf{H a})\end{array}$ \\
\hline 1 & Hutan menjadi Kebun campuran & 13.884 \\
\hline 2 & Hutan menjadi Ladang & 1.362 \\
\hline 3 & Kebun campuran menjadi Ladang & 0.057 \\
\hline 4 & Kebun campuran menjadi Semak belukar & 0.126 \\
\hline 5 & Kebun campuran menjadi Terbangun & 0.042 \\
\hline 6 & Ladang menjadi Terbangun & 0.175 \\
\hline 7 & Sawah menjadi Terbangun & 0.024 \\
\hline 8 & Semak belukar menjadi Ladang & 0.163 \\
\hline 9 & Semak belukar menjadi Terbangun & 0.050 \\
\hline & Total Perubahan & $\mathbf{1 5 . 8 8 3}$ \\
\hline
\end{tabular}

Sumber : Hasil olahan data Citra tahun 2002 dan 2014

Penggunaan lahan dari tahun 2002 ke tahun 2014 di Nagari Koto Gadang mengalami perubahan dimana penggunaan lahan hutan menjadi penggunaan lahan kebun campuran seluas 13.884 ha, perubahan penggunaan lahan hutan menjadi penggunaan lahan lading seluas 1.362 ha. Sedangkan ladang menjadi lahan terbangun seluas 0.175 ha, perubahan penggunaan lahan kebun campuran menjadi penggunaan ladang seluas 0.424 ha, perubahan semak belukar menjadi ladang adalah seluas 0.163 ha dan kebun campuran menjadi semak belukar seluas 0.126 ha. Dari total luas hutan yang 
berubah dari tahun 2002 ke 2014 yang paling besar adalah perubahan ke arah penggunaan lahan kebun campuran.

\section{Nagari Duo Koto}

Tabel 4. Luas perubahan penggunaan lahan di Nagari Duo Koto dari tahun 2002 sampai tahun 2014

\begin{tabular}{|l|l|l|}
\hline No. & $\begin{array}{l}\text { Kelas Perubahan Penggunaan Lahan } \\
\text { Nagari Duo Koto }\end{array}$ & $\begin{array}{l}\text { Luas } \\
(\mathbf{H a})\end{array}$ \\
\hline 1 & Hutan menjadi Kebun campuran & 6.151 \\
\hline 2 & Hutan menjadi Ladang & 0.213 \\
\hline 3 & Hutan menjadi Terbangun & 0.008 \\
\hline 4 & Kebun campuran menjadi Ladang & 0.554 \\
\hline 5 & Kebun campuran menjadi Semak belukar & 0.660 \\
\hline 6 & Kebun campuran menjadi Terbangun & 0.022 \\
\hline 7 & Ladang menjadi Terbangun & 0.497 \\
\hline 8 & Sawah menjadi Terbangun & 0.282 \\
\hline 9 & Semak belukar menjadi Ladang & 0.508 \\
\hline 10 & Semak belukar menjadi Terbangun & 0.183 \\
\hline & Total Perubahan & $\mathbf{9 . 0 7 8}$ \\
\hline & Sumber : Hasil olahan data Citra tahun 2002 dan & 2014 \\
\hline
\end{tabular}

Sumber : Hasil olahan data Citra tahun 2002 dan 2014

Penggunaan lahan dari tahun 2002 ke tahun 2014 di Nagari Duo Koto mengalami perubahan dimana penggunaan lahan hutan menjadi penggunaan lahan kebun campuran seluas 6.151 ha, perubahan penggunaan kebun campuran menjadi semak belukar seluas 0.660 ha. Sedangkan kebun campuran menjadi ladang seluas 0.554 ha, perubahan penggunaan lahan semak belukar menjadi ladang seluas 0.508 ha, perubahan ladang menjadi terbangun adalah seluas 0.497 ha dan kebun sawah menjadi terbangun seluas 0.282 ha, perubahan hutan menjadi ladang adalah seluas 0.213 ha, dan perubahan semak belukar menjadi terbangun seluas 0.183 ha. Dari total luas 
hutan yang berubah dari tahun 2002 ke 2014 yang paling besar adalah perubahan ke arah penggunaan lahan kebun campuran.

\section{Nagari Koto Malintang}

\section{Tabel 5. Luas perubahan penggunaan lahan di Nagari Koto Malintang dari tahun 2002 sampai tahun 2014}

\begin{tabular}{|l|l|l|}
\hline No. & $\begin{array}{l}\text { Kelas Perubahan Penggunaan Lahan } \\
\text { Nagari Koto Malintang }\end{array}$ & $\begin{array}{l}\text { Luas } \\
(\mathbf{H a})\end{array}$ \\
\hline 1 & Hutan menjadi Kebun campuran & 17.589 \\
\hline 2 & Hutan menjadi Ladang & 4.944 \\
\hline 3 & Kebun campuran menjadi Ladang & 0.049 \\
\hline 4 & Kebun campuran menjadi Semak belukar & 0.040 \\
\hline 5 & Kebun campuran menjadi Terbangun & 0.098 \\
\hline 6 & Ladang menjadi Terbangun & 0.313 \\
\hline 7 & Sawah menjadi Terbangun & 0.199 \\
\hline 8 & Semak belukar menjadi Kebun Campuran & 0.042 \\
\hline 9 & Semak belukar menjadi Ladang & 0.115 \\
\hline 10 & Semak belukar menjadi Terbangun & 0.308 \\
\hline & Total Perubahan & $\mathbf{2 3 . 6 9 7}$ \\
\hline & Sumber : Hasil olahan data Citra tahun 2002 dan & 2014 \\
\hline
\end{tabular}

Sumber : Hasil olahan data Citra tahun 2002 dan 2014

Penggunaan lahan dari tahun 2002 ke tahun 2014 di Nagari Koto Malintang mengalami perubahan dimana penggunaan lahan hutan menjadi penggunaan lahan kebun campuran seluas 17.589 ha, perubahan penggunaan hutan menjadi lading seluas 4.944 ha. Sedangkan Ladang menjadi lahan Terbangun seluas 0.313 ha, perubahan penggunaan lahan semak belukar menjadi terbangun seluas 0.308 ha, perubahan penggunaan lahan sawah menjadi terbangun seluas 0.199 ha, perubahan semak belukar menjadi lading adalah seluas 0.115 ha dan Kebun campuran menjadi Terbangun seluas 0.098 ha. Dari total luas hutan yang berubah dari tahun 2002 ke 2014 yang paling besar adalah perubahan ke arah penggunaan lahan kebun campuran. 


\section{Nagari Bayua}

Tabel 6. Luas perubahan penggunaan lahan di Nagari Bayua dari tahun 2002 sampai tahun 2014

\begin{tabular}{|l|l|l|}
\hline No. & $\begin{array}{l}\text { Kelas Perubahan Penggunaan Lahan } \\
\text { Nagari Bayua }\end{array}$ & $\begin{array}{l}\text { Luas } \\
(\mathbf{H a})\end{array}$ \\
\hline 1 & Hutan menjadi Kebun campuran & 14.756 \\
\hline 2 & Hutan menjadi Ladang & 1.516 \\
\hline 3 & Kebun campuran menjadi Ladang & 1.195 \\
\hline 4 & Kebun campuran menjadi Semak belukar & 0.173 \\
\hline 5 & Kebun campuran menjadi Terbangun & 0.032 \\
\hline 6 & Ladang menjadi Terbangun & 1.166 \\
\hline 7 & Sawah menjadi Terbangun & 0.649 \\
\hline 8 & Semak belukar menjadi Ladang & 0.424 \\
\hline 9 & Semak belukar menjadi Terbangun & 0.199 \\
\hline & Total Perubahan & $\mathbf{2 0 . 1 1 0}$ \\
\hline & Sumber : Hasil Olahan data Citra tahun 2002 dan & 2014 \\
\hline
\end{tabular}

Sumber : Hasil olahan data Citra tahun 2002 dan 2014

Penggunaan lahan dari tahun 2002 ke tahun 2014 di nagari bayua mengalami perubahan dimana penggunaan lahan hutan menjadi penggunaan lahan kebun campuran seluas 14.756 ha, perubahan penggunaan hutan menjadi lading seluas 1.516 ha. Sedangkan kebun campuran menjadi ladang seluas 1.195 ha, perubahan penggunaan sawah menjadi terbangun seluas 0.308 ha, perubahan penggunaan lahan sawah menjadi terbangun seluas 0.649 ha, perubahan semak belukar menjadi lading adalah seluas 0.424 ha dan semak belukar menjadi terbangun seluas 0.199 ha. Total luas hutan yang berubah dari tahun 2002 ke 2014 yang paling besar adalah perubahan ke arah penggunaan lahan kebun campuran. 


\section{Nagari Maninjau}

Tabel 7. Luas perubahan penggunaan lahan di Nagari Maninjau dari tahun 2002 sampai tahun 2014

\begin{tabular}{|l|l|l|}
\hline No. & $\begin{array}{l}\text { Kelas Perubahan Penggunaan Lahan } \\
\text { Nagari Maninjau }\end{array}$ & $\begin{array}{l}\text { Luas } \\
(\mathbf{H a})\end{array}$ \\
\hline 1 & Hutan menjadi Kebun campuran & 2.358 \\
\hline 2 & Hutan menjadi Ladang & 0.075 \\
\hline 3 & Kebun campuran menjadi Ladang & 0.167 \\
\hline 4 & Kebun campuran menjadi Semak belukar & 0.074 \\
\hline 5 & Ladang menjadi Terbangun & 0.253 \\
\hline 6 & Sawah menjadi Terbangun & 0.025 \\
\hline 7 & Semak belukar menjadi Ladang & 0.148 \\
\hline & Total Perubahan & $\mathbf{3 . 1 0 0}$ \\
\hline
\end{tabular}

Sumber : Hasil olahan data Citra tahun 2002 dan 2014

Penggunaan lahan dari tahun 2002 ke tahun 2014 di nagari maninjau mengalami perubahan dimana penggunaan lahan hutan menjadi penggunaan lahan kebun campuran seluas 2.358 ha, perubahan penggunaan ladang menjadi terbangun seluas 0.253 ha. Sedangkan kebun campuran menjadi ladang seluas 0.167 ha, perubahan penggunaan semak belukar menjadi ladang seluas 0.148 ha, perubahan penggunaan hutan menjadi ladang seluas 0.075 ha. Total luas hutan yang berubah dari tahun 2002 ke 2014 yang paling besar adalah perubahan ke arah penggunaan lahan kebun campuran. 


\section{Nagari Sungai Batang}

Tabel 8.Luas perubahan penggunaan lahan di Nagari Sungai Batang dari tahun 2002 sampai tahun 2014

\begin{tabular}{|l|l|l|}
\hline No. & $\begin{array}{l}\text { Kelas Perubahan Penggunaan Lahan } \\
\text { Nagari Sungai Batang }\end{array}$ & $\begin{array}{l}\text { Luas } \\
(\text { Ha })\end{array}$ \\
\hline 1 & Hutan menjadi Kebun campuran & 31.831 \\
\hline 2 & Hutan menjadi Ladang & 5.610 \\
\hline 3 & Kebun campuran menjadi Ladang & 0.968 \\
\hline 4 & Kebun campuran menjadi Semak belukar & 1.066 \\
\hline 5 & Kebun campuran menjadi Terbangun & 0.130 \\
\hline 6 & Ladang menjadi Terbangun & 0.593 \\
\hline 7 & Sawah menjadi Terbangun & 0.057 \\
\hline 8 & Semak belukar menjadi Kebun Campuran & 0.016 \\
\hline 9 & Semak belukar menjadi Ladang & 0.717 \\
\hline 10 & Semak belukar menjadi Terbangun & 0.315 \\
\hline & Total Perubahan & $\mathbf{4 1 . 3 0 3}$ \\
\hline
\end{tabular}

Sumber : Hasil olahan data Citra tahun 2002 dan 2014

Penggunaan lahan dari tahun 2002 ke tahun 2014 di nagari sungai batang mengalami perubahan dimana penggunaan lahan hutan menjadi penggunaan lahan kebun campuran seluas 31.831 ha, perubahan penggunaan hutan menjadi ladang seluas 5.610 ha. Sedangkan kebun campuran menjadi semak belukar seluas 1.066 ha, perubahan penggunaan kebun campuran menjadi ladang seluas 0.968 ha, perubahan penggunaan semak belukar menjadi ladang seluas 0.717 ha, perubahan penggunaan ladang menjadi terbangun seluas 0.593, perubahan penggunaan semak belukar menjadi terbangun seluas 0.315 total luas hutan yang berubah dari tahun 2002 ke 2014 yang paling besar adalah perubahan ke arah penggunaan lahan kebun campuran. 


\section{Nagari Tanjung Sani}

Tabel 9.Luas perubahan penggunaan lahan di Nagari Tanjung Sani dari tahun 2002 sampai tahun 2014

\begin{tabular}{|l|l|l|}
\hline No. & $\begin{array}{l}\text { Kelas Perubahan Penggunaan Lahan } \\
\text { Nagari Tanjung Sani }\end{array}$ & $\begin{array}{l}\text { Luas } \\
(\mathbf{H a})\end{array}$ \\
\hline 1 & Hutan menjadi Kebun campuran & 30.565 \\
\hline 2 & Hutan menjadi Ladang & 5.842 \\
\hline 3 & Kebun campuran menjadi Ladang & 0.336 \\
\hline 4 & Kebun campuran menjadi Semak belukar & 0.460 \\
\hline 5 & Kebun campuran menjadi Terbangun & 0.314 \\
\hline 6 & Ladang menjadi Terbangun & 1.231 \\
\hline 7 & Sawah menjadi Terbangun & 0.315 \\
\hline 8 & Semak belukar menjadi Kebun Campuran & 0.376 \\
\hline 9 & Semak belukar menjadi Ladang & 1.067 \\
\hline 10 & Semak belukar menjadi Terbangun & 0.914 \\
\hline & Total Perubahan & $\mathbf{4 1 . 4 2 0}$ \\
\hline
\end{tabular}

Sumber : Hasil olahan data Citra tahun 2002 dan 2014

Penggunaan lahan dari tahun 2002 ke tahun 2014 di nagari tanjung sani mengalami perubahan dimana penggunaan lahan hutan menjadi penggunaan lahan kebun campuran seluas 30.565 ha, perubahan penggunaan hutan menjadi ladang seluas 5.842 ha. Sedangkan ladang menjadi terbangun seluas 1.231 ha, perubahan penggunaan semak belukar menjadi ladang seluas $1.067 \mathrm{ha}$, perubahan penggunaan semak belukar menjadi ladang seluas 0.717 ha, perubahan penggunaan semak belukar menjadi terbangun seluas 0.593 ha, perubahan penggunaan semak belukar menjadi terbangun seluas 0.9 14ha. Total luas hutan yang berubah dari tahun 2002 ke 2014 yang paling besar adalah perubahan ke arah penggunaan lahan kebun campuran. 
Penggunaan lahan merupakan wujud dari kegiatan manusia dalam memperlakukan sebidang tanah. Karakteristik penggunaan lahan pada suatu daerah yang dapat diambil informasi keruangannya dengan memanfaatkan teknologi penginderaan jauhdan ditambah dengan cros cek lapangan.

Berdasarkan interpretasi citra dan pengecekan dilapangan, terdapat delapan (8) jenis penggunaan lahan yakni; tanah terbuka, hutan, ladang, daerah terbangun, persawahan, semak belukar, kebun campuran, dan danau. Ditemukan bahwa hutan masih mendominasi penggunaan lahan di Kawasan Danau Maninjau. pada tahun 1989 luas hutan 32.350.59 ha. Tahun 2002 terjadi perubahan yang mencolok pada penggunaan lahan hutan yaitu pengurangan drastis luas hutan sehingga tersisa 27.580 .50 ha. Sedangkan pada tahun 2014 lahan hutan berkurang menjadi 20.175.93 ha. Berdasarkan hal tersebut terlihat pemanfatan lahan begitu dinamis dari pola dan aktivitas manusia di kawasan danau maninjau. Kegiatan manusia yang memerlukan bahan pangan, air, energi dan minyak serta infrastruktur perumahan dan fasilitas publik di Kawasan Danau maninjau membuat luas hutan jauh berkurang.

Perubahan penggunaan lahan adalah perubahan penggunaan atau aktivitas terhadap suatu lahan yang berbeda dari aktivitas sebelumnya, baik untuk tujuan komersial maupun industri (Kazaz dan Charles, 2001 dalam Munibah, 2008). Sementara menurut Muiz (2009), perubahan penggunaan lahan diartikan sebagai suatu proses perubahan dari penggunaan lahan sebelumnya ke penggunaan lain yang dapat bersifat permanen maupun sementara dan merupakan konsekuensi logis dari adanya pertumbuhan dan transformasi perubahan struktur sosial ekonomi masyarakat. Setiap tahunnya terjadi perubahan penggunaan lahan di kawasan danau Maninjau karena konsekuensi dari adanya pertumbuhan dan peningkatan permintaan jenis 
lahan tertentu. Perubahan penggunaan lahan dari tahun 1989 sampai pada tahun 2014 dapat dilihat arah perubahannya. Perubahan penggunaan lahan hutan dari tahun 1989 ke tahun 2002 terlihat berubah kearah kebun campuran seluas 3.687,48 ha. Kemudian dari tahun 2002 sampai tahun 2014 perubahan penggunan lahan hutan berubah menjadi penggunaan lahan kebun campuran seluas $6.262,65$ ha.

Tanah merupakan salah satu faktor penentu yang mempengaruhi penyebaran penggunaan lahan (Barlowe, 1986). Sehubungan dengan fungsinya sebagai sumber hara, tanah merupakan faktor fisik lahan yang paling sering dimodifikasi agar penggunaan lahan yang diterapkan mendapatkan hasil yang maksimal. Di kawasan danau Maninjau tanahjuga menjadi faktor penentu karena di kawasan inipekerjaan penduduk yang paling banyak adalah bidang pertanian 13.978 orang (72,47\%). Dilihat per nagari, terlihat perubahan penggunaan lahan. Penggunan lahan hutan paling luas yang diubah menjadi lahan pertanian. Perubahan penggunaan lahan hutan yang menjadi lahan pertanian paling luas terjadi di Nagari Tanjung Sani di barat danau Maninjau (30.565 ha) dan di Nagari Sungai Batang ditimur danau Maninjau (31.831 ha).

\section{PENUTUP}

1. Penggunaan tanah di Kawasan Danau Maninjau dapat diklasifikasi berdasarkan delapan (8) jenis penggunaan lahan yakni; tanah terbuka, hutan, ladang, daerah terbangun, persawahan, semak belukar, kebun campuran, dan danau, yang paling luas adalah hutan seluas 32.350 .59 ha tahun 1989. Tahun 2002 luas hutan adalah 27.580 .50 ha dan di tahun 2014 luas hutan hanya menjadi 20.175.93 ha.

2. Pola perubahan penggunaan tanah secara spasial di Kawasan Danau Maninjau mengikuti kegiatan utama sebagian besar penduduk di bidang 
pertanian. Lahan hutan paling banyak diubah menjadi lahan pertanian kebun campuran. Lahan hutan yang diubah menjadi kebun campuran paling luas terdapat di Nagari Tanjung Sani di sebelah barat danau Maninjau (30.565 ha) dan di Nagari Sungai Batang di sebelah timur danau Maninjau (31.831 ha).

\section{DAFTAR PUSTAKA}

Asdak, C. 2002. Hidrologi dan Pengelolaan Daerah Aliran Sungai. Yogyakarta: Gadjah Mada University Press

Arnoff. S. 1993. Geographic Information System : A Management Perspective. Ottawa Canada : WDL Publications.

Asnil. 2012. Analisis Penilaian Ekonomi dan Kebijakan Pemanfaatan Sumberdaya Danau yang Berkelanjutan (Studi Kasus Danau Maninjau Sumatera Barat). Bogor : Pasca Sarjana Institut Pertanian Bogor.

Barus B, US Wiradisastra. 2000. Sistem Informasi Geografi : Sarana Manajemen Wilayah. Bogor : Lab. Indraja dan Kartografi.

Cheng, J. 2003. Modelling spatial and temporal land use growth. Doctoral Dissertation, Faculty of Geographycal Science. Utretch University. Utretch, The Netherlands.

Kartika, T, dkk. 2012. Analisis Perubahan Penutup Lahan di Daerah Tangkapan Air Sub Das Tondano Terhadap Kualitas Danau Tondano Menggunakan Data Satelit Penginderaan Jauh. Seminar Nasional Limnologi VI 2012 Pusat Pemanfaatan Penginderaan Jauh LAPAN.

Kartono, Hari, dkk. 1989. Esensi Pembangunan Wilayah dan Penggunaan Tanah Berencana. Jakarta: Geografi-FMIPA UI.

[Kemen-LH] Kementerian Negara Lingkungan Hidup. 2008. Konsep pedoman umum pengelolaan ekosistem danau. Jakarta. $125 \mathrm{hlm}$.

Lillesand, Thomas, M. and Kiefer Ralph, W. 1994. Remote Sensing and Image Interpretation. Third Edison. New York : Jhon Wiley \& Son, Inc.

Marganof. 2007. Model Pengendalian Pencemaran Perairan Di Danau Maninjau Sumatera Barat. Bogor : Pascasarjana Institut Pertanian Bogor.

Nasution, Zahri, dkk. 2011. Perikanan Budidaya Di Danau Maninjau: Antisipasi Kebijakan Penanganan Dampak Kematian Ikan Massal. 
Jakarta : Balai Besar Penelitian Sosial Ekonomi Kelautan dan Perikanan,

Peraturan Pemerintah Republik Indonesia Nomor 47 Tahun 1997 tentang Rencana Tata Ruang Wilayah Nasional.

Rustiadi E, Saefullah S, Panuju DR. 2009. Perencanaan dan Pengembangan Wilayah. Edisi Juli 2007. Bogor: Fakultas Pertanian Institut Pertanian Bogor

Sandy, I Made. 1985. Republik Indonesia Geografi Regional. Jakarta: Geografi-FMIPA UI.

Soemarwoto O. 2004. Ekologi, lingkungan hidup dan pembangunan. Penerbit Djambatan. Bandung. xiii $+382 \mathrm{hlm}$.

Turner, R.K., R. Brouwer, S. Georgiou and I. J. Bateman, 2000. Ecosystem functions and services : an integrated framework and case study for environmental evaluation. The Centre for Social and Economic Research on the Global Environment (CSERGE),UK.

Undang-Undang Nomor 26 Tahun 2007 Tentang Penataan Ruang.

Wardjan Y. 2005. Seleksi Lokasi dan Estimasi Daya Dukung Lingkungan Perairan untuk Budidaya Ikan Kerapu Teknik Keramba Jaring Apung Diperairan Pulau Panikiang Kabupaten Barru, Sulawesi Selatan. Tesis SPs IPB. Bogor. 